\title{
Strategi Dakwah dan Faktor Pengaruh
}

\author{
Najamuddin \\ Fakultas Dakwah Univeritas Islam Negeri Mataram \\ najamuddin@gmail.com
}

\begin{abstract}
Along with the development of today's world with all existing dynamics, every organization oriented to the development of Islamic da'wah is required to be able to formulate a strategy and its application. On the other hand it is also demanded to be able to improve itself in getting around the da'wah, so what message of syar'i can be accepted by mad'u (object of preaching). No exception for a profit organization (non-profit), and any da'wah organization that is purposeful existence and survival, then it must be able to determine every policy direction and to implement the right strategy to carry out its vision, mission, and to anticipate all possibilities, so what which became the ideals and goals of the organization can be achieved. Seeing the description of the phenomenology mentioned above, surely we realize that the role of strategy for the activities of da'wah is very important in determining an organization's policy steps. Then, related to the concepts, strategies, opportunities and challenges of the da'wah the writer will discuss in this article.
\end{abstract}

Keyword: Strategy, Da'wah and Its Challenges.

\section{Pendahuluan}

Dalam konstelasi kehidupan di dunia ini manusia tentunya tidak bisa terlepas dari apa yang dinamakan dengan agama. Hal tersebut dikarenakan agama sangatlah inhern dalam kehidupan 
sosial manusia dengan segala dinamika yang ada. Hal tersebut mengandung arti bahwa manusia dalam aktivitasnya tidak bisa terlepas dari nilai-nilai agama yang ada di dalamnya. Dalam hal ini Islam adalah agama bagi umat manusia yang di dalamnya memuat pesan yang bersifat universal dan abadi dikarenakan ajaranya akan selalu mengikat selama dalam masa taklif (mukallaf). Konsekuensi tersebut tertuang dalam suguhan konsepsi hukum Islam yang menjamin perbaikan dan peningkatan kehidupan umatnya baik di dunia maupun di akhirat. Islam adalah pandangan hidup yang lengkap (kaffah), membimbing sesuai petunjuk-petunjuk Allah SWT, sebagaimana yang disampaikan oleh Rasul-Nya Muhammad SAW. ' Secara praktis, Islam menuntut para pemeluknya untuk senantiasa menyeru, mengajak, dan menyampaikan ajaranya agar apa yang menjadi pesan agama dapat disebarluaskan ke seluruh alam semesta. ${ }^{2}$ Hal tersebut merupakan suatu kewajiban yang harus dilaksanakan oleh setiap umat Islam, yang tentunya dalam penyampaian misi dakwah yang diterapkanya dalam rangka mengajak manusia kepada ajaran Islam haruslah mengacu pada apa yang telah dicontohkan oleh Rosulullah Muhammad SAW. ${ }^{3}$ Mengenai kewajiban menyampaikan dakwah Islam, Allah SWT berfirman dalam ayat suci Al-Qur'an:

\section{Artinya:}

"Serulah (manusia) kepada jalan Tuhan-mu dengan hikmah, dan pelajaran yang baik dan bantahlah mereka dengan cara yang baik. Sesungguhnya Tuhanmu Dialah yang lebih mengetahui tentang siapa yang tersesat dari jalan-Nya dan Dialah yang lebih mengetahui orang-orang yang mendapat petunjuk." (An-Nahl: 125).

${ }^{1}$ Begum A'isyah Bawany, Mengenal Islam Selayang Pandang, Terj. Machnun Husein, (Jakarta: Bumi Aksara, 1994), 5

${ }^{2}$ Konsep tentang menyeru, mengajak, menyempaikan dan mempengaruhi tersebut yang kemudian dinamakan dengan dakwah. Lihat pengertian dakwah Awaludin Pimay, Metodologi Dakwah; Kajian Teoritis dari Khazanah Al-Qur'an, (Semarang: Rasail, 2006), 2.

${ }^{3}$ Mohammad Natsir, Fiqhud Da'wah, (Jakarta: Media Da'wah, 2000), 125. 
Hermeneutika kata $u d$ ' $u$ yang selanjutnya ditafsirkan dengan "seruan" yang merupakan fiil amr, yang dalam kaidah ushul fiqh merujuk kepada hukum wajib mengindikasikan bahwa dakwah mutlak harus direalisasikan di dalam setiap sendi-sendi kehidupan. ${ }^{4}$ Telah menjadi suatu yang ma'lum, bahwasanya Islam adalah agama dakwah yang mengandung arti bahwa keberadaanya di muka bumi ini adalah dengan disebarluaskan dan diperkenalkan kepada seluruh umat melalui aktivitas dakwah, bukan dengan paksaan, kekerasan, dan tidak pula dengan kekuatan pedang. Hal ini dapat dipahami, karena Islam sendiri adalah agama pembawa perdamaian, agama cinta kasih, agama pembebasan dari belenggu perbudakan, dan juga mengakui hak dan kewajiban setiap individu. Ini berarti anggapan para oreientalis yang selama ini mengatakan Islam adalah agama yang kejam, menakutkan dan dikenal dengan radikalismenya adalah tidak benar adanya. Statemen demikian tentunya amatlah tidak sesuai, dikarenakan bila kita mencoba menelaah dalam Al-Qur'an yaitu pada surat Al-Baqoroh ayat 256, Allah berfirman:

\section{Artinya:}

"Tidak ada paksaan untuk (memasuki) agama (Islam); Sesungguhnya telah jelas jalan yang benar daripada jalan yang sesat. karena itu Barangsiapa yang ingkar kepada Thaghut dan beriman kepada Allah, Maka Sesungguhnya ia telah berpegang kepada buhul tali yang Amat kuat yang tidak akan putus. dan Allah Maha mendengar lagi Maha mengetahui”. (Al-Baqoroh: 256).

Dari ayat di atas dapat kita fahami, bahwa dalam memilih suatu agama tidaklah boleh dipaksakan, termasuk di dalamnya adalah berdakwah dan menyampaikan ajaran Islam. ${ }^{5}$ Hal senada

${ }^{4}$ Kewajiban berdakwah sesuai dengan surat An-Nahl ayat: 125, merupakan kewajiban mutlak (absolut). Hal tersebut dikarenakan para Ulama' telah bersepakat mengenai hokum wajibnya, hanya saja diantara mereka ada yang mengatakan wajib 'ainiyah (berlaku universal/setiap orang), dan Ulama' lain mengatakan wajib kifayah (dalam arti apabila alam satu kelompok sudah ada yang menjalankanya maka gugurlah kewajiban tersebut). Baca: Aminuddin Sanwar, Pengantar Ilmu Dakwah, (Semarang: Fakultas dakwah, 1986), 34.

${ }^{5}$ Larangan memaksakan suatu agama seperti dicontohkan oleh Rosulullah 
diungkapkan oleh Ulil Abshar Abdalla yang merupakan tokoh Jaringan Islam Liberal (JIL), menurutnya dalam pandangan Islam, memeluk agama adalah merupakan suatu pilihan yang dilakukan secara sadar, artinya tidak boleh ada unsur paksaan Sedikitpun. ${ }^{6}$ Dari hal tersebut di atas, seyogyanya di dalam melakukan aktifitas berdakwah pendekatan yang seharusnya dilakukan adalah dengan cara yang halus, lembut dan santun sebagaimana tersebut dalam surat An-Nahl di atas.

\section{Konsep Dasar Strategi Dakwah}

Strategi pada mulanya merupakan suatu istilah yang diadopsi dari kalangan militer, yang merujuk pada penggunaan dan pemanfaata dana, daya dan peralatan yang tersedia untuk memenangkan pertempuran. Akan tetapi dewasa ini sesuai dengan perkembangan kehidupan pada abad modern, istilah tersebut ternyata tidak hanya digunakan dalam istilah militer saja, akan tetapi juga digunakan oleh berbagai organisasi non militer tak terkecuali di dalamnya, yaitu organisasi masyarakat seperti Nahdlatul Ulama' (NU) di dalam pengembangan dakwahnya. Hal tersebut tiada lain dikarenakan dakwah merupakan suatu aktifitas untuk mengajak manusia menuju suatu tujuan ${ }^{7}$, yang dalam hal ini tujuan tersebut tiada lain yaitu menuju ke jalan Allah. Esensi tersebut tertuang dalam firman Allah surat An-Nahl ayat: 125

ketika tinggal di Madinah, dimana penduduk Madinah sebelum kedatangan Islam, mereka adalah pemeluk agama Yahudi, dan disana banyak terjadi orang tua yang telah memeluk Islam akan tetapi anaknya memilih Yahudi. Hal tersebut dirasa kehidupan Yahudi jauh lebih baik bagi mereka. Dan hal ini pulalah yang menjadi sabab nuzul ayat di atas. Fathul Bahri, Meniti Jalan Dakwab; Bekal Perjungan Para Da'I, (Jakarta: Sinar Grafika, 2008), 13-15.

${ }^{6}$ Mengenai hal yang berkaitan dengan memilih suatu agama (keimanan) dapat kita lihat dalam surat Al-Kahfi ayat: 29, Ulil Abshar Abdalla, Menyegarkan Kembali Pemikiran Islam; Bunga Rampai Surat-surat Tersiar, (Jakarta: Nalar, 2007), 165.

${ }^{7}$ Tujuan tersebut yang kemudian digaris bawahi oleh M. Ridlo Syabibi, agar apa yang menjadi tujuan dari aktifitas dakwah dapat diterima secara efektif dan efisien mutlak diperlukan kiat-kiat dan strategi khusus. Hal inilah yang olehnya dinamakan strategi dakwah. Baca: M. Ridlo Syabibi, Metodologi Ilmu Dakwab; Kajian Ontologis Dakwah Ikhwan Al-Safa, (Yogyakarta: Pustaka Pelajar, 2008), 135. 


\section{Artinya:}

"Serulah (manusia) kepada jalan Tuhan-mu dengan hikmah dan pelajaran yang baik dan bantahlah mereka dengan cara yang baik. Sesungguhnya Tuhanmu Dialah yang lebih mengetahui tentang siapa yang tersesat dari jalan-Nya dan Dialah yang lebih mengetahui orang-orang yang mendapat petunjuk." (An-Nahl ayat: 125).

Dari ayat di atas, kita dapat mengetahui bahwa di dalamnya juga memuat metodologi atau cara-cara yang harus diterapkan dalam melaksanakan suatu aktifitas dakwah, yang tentunya harus disesuaikan dengan kemajuan dan perkembangan zaman (sholih $f i$ kulli zaman wa al- makan). Dengan kata lain, konsepsi tentang dakwah atau menyeru ke jalan Allah seperti yang tersebut dalam ayat di atas mengindikasikan, bahwa kewajiban dakwah harus mempertimbangkan berbagai cara ataupun strategi yang ditempuh dengan tanpa mengabaikan kondisi mad'u (objek dakwah). ${ }^{8}$

Memahami arti dari sebuah kata "strategi" memanglah tidak mudah, hal tersebut dikarenakan setiap literatur yang didapat antara satu dengan yang lain seringkali memberikan definisi yang berbeda, bahkan bisa dikatakan sampai saat ini tidak ada definisi yang baku mengenai istilah tersebut. Hal tersebut mengandung arti bahwa istilah strategi mempunyai ruang lingkup yang sangat luas dan tidak terbatas, sesuai dengan setiap kata yang merangkainya seperti pada istilah strategi dakwah.

Perlu difahami bersama, bahwasanya istilah strategi dakwah merupakan kombinasi dari dua disiplin ilmu yang berbeda. Akan tetapi secara konseptual-skematis, dalam penelitian ini akan dijelaskan pengertian satu persatu, kemudian setelah ditemukan

${ }^{8}$ Kewajiban melaksanakan dakwah dengan pola-pola seperti hikmah, mau'idzoh basanab dan mijadalah yaitu disebut dengan pola-pola dakwah yang mempertimbangkan keadaan objek dakwah yang oleh Ahmad Anas disebut dengan pendekatan dakwah yang mengacu pada buman relation. Lihat: Ahmad Anas, Paradigma Dakwah Kontemporer; Aplikasi Teoritis dan Praktis Dakwah sebagai Solusi Problematika Kekinian, (Semarang: Pustaka Rizki Putra, 2006), 116-117. 
kejelasan masing-masing barulah akan ditarik suatu kesimpulan dan didefinisikan menjadi satu. Pada dasarnya istilah strategi yaitu berasal dari kata Yunani Strategos yang berarti Jenderal. Penggunaan istilah tersebut pertama kali, yaitu dipopulerkan oleh kalangan militer. Dalam kamus induk disebutkan, strategi yaitu kiat atau cara-cara yang baik dan menguntungkan dalam setiap tindakan. ${ }^{9}$ Penggunaan istilah strategi di kalangan militer biasanya lebih didominasi dalam situasi peperangan, sebagai tugas komandan dalam menghadapi musuh, yang bertanggung jawab mengatur cara atau taktik untuk memenangkan peperangan.

Dalam pengertian di atas, strategi juga dapat dipahami sebagai suatu seni para jenderal dalam menjalankan taktiknya di medan pertempuran. Dari sudut etimologis strategi dalam sebuah organisasi dapat diartikan yaitu sebagai suatu kiat, cara dan taktik yang dirancang secara sistematis dan terarah dalam melaksanakan fungsi-fungsi organisasi. ${ }^{10}$ Starategi juga dipahami sebagai segala cara dan daya untuk menghadapi sasaran tertentu dalam kondisi tertentu agar memperoleh hasil yang diharapkan secara maksimal. Kalau merujuk kepada ayat Al-Qur'an, sebenarnya di sana juga terdapat ayat-ayat yang mengindikasikan tentang strategi. Di antara ayat yang menerangkan hal tersebut yaitu seperti yang terdapat dalam Surat An-Nisa' ayat 71:

\section{Artinya:}

"Hai orang-orang yang beriman, bersiap siagalah kamu, dan majulah (ke medan pertempuran) berkelompok- kelompok, atau majulah bersama-sama”. (An-Nisa: 71)

Wahbah Az-Zuhaili dalam Tafsir Munir memaknai lafadz "khudzuu khidzrokum" dengan lafadz "ikhtarizuu wa tayaqqodzu", maksudnya yaitu berhati-hati dan bangun untuk melawan musuh.

9 M. Dahlan, Lya Sofwan, Kamus Induk Istilab Ilmiah, (Surabaya: Target Press, 2003), 740.

${ }^{10}$ Hadari Nawawi, Manajemen Strategik; Organisasi Non Profit Bidang Pemerintahan dengan Ilustrasi di Bidang Pendidikan, (Yogyakarta: Gajahmada University Press, 2005), 147. 
Sedangkan dalam lafadz "fan firuu" diartikan dengan "inhadzuu ila qitalihi" yang bermakna bangkit memerangi musuh. ${ }^{11}$ Strategi sesuai ayat di atas yaitu dapat bermakna kehati-hatian, sikap siaga dan waspada terhadap musuh, serta berusaha bangkit untuk menyerangnya. Dalam suatu organisasi, sebelum menentukan kebijakan-kebijakan pastilah dituntut untuk bersikap hati-hati dan waspada dalam menyusun suatu kebijakan. Hal tersebut dimaksudkan agar kinerja suatu organisasi dapat terkontrol dan terarah sesuai dengan haluan kebijakan yang telah ditetapkan.

Menurut M. Quraisy Shihab dalam tafsir Al-Misbah, ayat di atas mengandung makna yaitu kehati-hatian, serta menghadapi musuh dengan upaya mengetahui kekuatan dan kelemahan mereka, serta cara-cara yang paling tepat untuk menangkis dan melumpuhkan mereka. Ayat Al-Qur'an di atas juga menjelaskan bagaimana kita dituntut untuk dapat mengelola dan mengatur pertempuran agar kita bisa meraih suatu kemenangan. ${ }^{12}$

Konsepsi tentang strategi ternyata dewasa ini tidak hanya dipergunakan oleh kalangan militer, akan tetapi oleh berbagai organisasi non militer. Dalam hal ini strategi yaitu bersinggungan dengan masalah-masalah yang berkaitan dengan efektivitas dan efisiensi. Dengan demikian strategi dalam sebuah organisasi haruslah memamfaatkan kemampuan organisasi sedemikian rupa, dengan memperhitungkan kesempatan dan resiko yang timbul, sehingga pemanfaatan kemampuan organisasi tersebut mendatangkan efektifitas dan efisiensi yang akan dacapai dalam waktu tertentu. Ciri-ciri yang tercipta dengan pemanfaatan dana, daya dan tenaga yang sesuai dengan perubahan lingkunganlah yang dimaksud dengan srategi. ${ }^{13}$

11 Wahbah Az-Zuhaili, Al-Tafsiiru Al-Muniiru; fi Al-Aqiidah, wa AsSyariah wa Al-Manhaj, (Beirut: Darul Fikri, 1991), 150.

${ }^{12}$ M. Quraisy Shihab, Tafsir Al-Misbab; Pesan, Kesan, dan Keserasian AlQur'an, (Jakarta: Lentera Hati, 2002), 503.

13 Sondang P. Siagian, Analisis serta Perumusan Kebijaksanaan dan Struktur Organisasi, (Jakarta: CV. Haji Masagung, 1994), 16-17. 
Strategi seperti yang dikemukakan oleh para ahli sebagai berikut: Pertama, Menurut Karl Van Calusewitz. Menurutnya strategi diartikan sebagai suatu seni bagi tentara dalam sebuah pertempuran. Kedua, Menurut Drucer. Strategi adalah mengerjakan sesuatu yang benar (doing the right things). ${ }^{14}$ Dari kedua pengertian di atas, dapat dipahami bahwa strategi tidaklah sebatas dalam cakupan wilayah teori saja, akan tetapi strategi juga include dalam segi aplikasi dan implementasi.

Dari pemaparan di atas, dapat diambil beberapa pengertian tentang strategi yaitu: strategi dapat diartikan sebagai kerangka atau rencana yang mengintegrasikan tujuan-tujuan (goals), kebijakankebijakan (policies) dan tindakan atau program organisasi. Strategi adalah suatu cara bagaimana suatu organisasi dapat mencapai suatu tujuan yang diinginkan pada masa yang akan datang. Strategi adalah pola tindakan dan alokasi sumber daya yang dirancang untuk mencapai tujuan organisasi. ${ }^{15}$

\section{Dakwah dalam Perpektii Ulama}

Dakwah bila kita tinjau dari perspektif etimologi yaitu berasal dari bahasa Arab yaitu: ${ }^{16}$ Kata tersebut secara leksikal memiliki arti seruan, panggilan dan ajakan. Adapun terminologi dakwah seperti diungkapkan oleh para ahli adalah sebagai berikut: ${ }^{17}$

1. Syekh Ali Mahfud dalam kitabnya Hidayatul Mursyidin beliau mengungkapkan: Yang berarti dakwah adalah mengajak manusia untuk mengerjakan kebaikan dan mengikuti petunjuk (Al-Huda), menyuruh mereka berbauat baik dan melarang mereka dari perbutan yang jelek agar mereka mendapat kebahagiaan dunia dan akhirat.

14 Sri Wahyudi, Manajemen Strategik; Pengantar Berfikir Strategik, Jakarta: Binarupa Aksara,1996), 16.

15 Tripomo, MT, Manajemen Strategi, (Bandung: Rekayasa Sains, 2005), 17.

16 M. Munir, Wahyu Ilaihi, Manajemen Dakwah, (Jakarta: Kencana, 2006), 17.

17 Aminuddin Sanwar, Pengantar Ilmu Dakwah, 2-3. 
2. Menurut syaikhul Islam Ibnu Taimiyah, dakwah adalah mengajak seseorang agar beriman kepada Allah dan apa yang dibawa oleh para Rosul dengan membenarkan apa yang mereka beritakan, dan mengikuti apa yang mereka perintahkan.

3. Abu Bakar Aceh beliau mengungkapkan: dakwah adalah perintah mengadakan seruan kepada semua manusia untuk kembali dan hidup sepanjang ajaran Allah yang benar, dilakukan dengan penuh kebijaksanaan dan nasehat yang baik.

4. H. M. Thoha Yahya Omar. Dakwah adalah mengajak manusia dengan cara bijaksana kepada jalan yang benar sesuai dengan perintah Tuhan untuk kemaslahatan dan kebahagiaan di dunia dan di akherat.

5. Abdul Karim Zaidan. Dakwah adalah merupakan panggilan ke jalan Allah.

Dari beberapa pengertian di atas, dapat difahami bahwasanya eksistensi dakwah pada intinya yaitu merupakan ajakan atau panggilan yang diarahkan pada masyarakat luas untuk menerima kebaikan dan meninggalkan keburukan sesuai dengan koridor syara'. Selain itu dakwah juga merupakan suatu usaha untuk menciptakan situasi yang lebih baik sesuai dengan ajaran- ajaran Islam dalam setiap lini kehidupan.

Dari penjelasan di atas, strategi dakwah dapat diartikan sebagai suatu proses dalam mengatur, mengarahkan, dan menentukan cara daya dan upaya untuk menghadapi sasaran dakwah dalam situasi dan kondisi tertentu agar apa yang menjadi tujuan dan sasaran dakwah dapat tercapai secara maksimal. Dengan kata lain strategi dakwah merupakan siasat, taktik atau cara yang dirancang secara sistematik dan terarah yang ditempuh dalam rangka mencapai tujuan dakwah. Hal demikian tentunya mengindikasikan bahwasanya keberadaan daripada apa yang dinamakan sebagai strategi dakwah adalah mempunyai peran yang sangat penting dalam suatu organisasi dakwah. 


\section{Faktor Pengaruh Strategi Dakwah}

Keberhasilan suatu organisasi dalam mencapai tujuan dan berbagai sasaranya akan cenderung ditentukan oleh dinamika organisasi yang bersangkutan. Dinamika yang tercipta dalam sebuah organisasi tersebut sejatinya disebabkan oleh adanya interaksi yang terjadi baik antara organisasi dengan lingkunganya, maupun satuan-satuan kerja dalam organisasi tersebut. Pada giliranya interaksi yang terjadi merupakan suatu akibat dan bukan merupakan tuntutan dari interdependensi yang terdapat antara organisasi dengan lingkunganya dan antara berbagai sub sistem dalam organisasi.

Dinamika yang mutlak terjadi dalam organisasi dakwah, mendorongnya untuk meningkatkan kemampuan dalam perumusan strategi yang diterapkan. Pada titik tertentu dinamika itulah yang akan mempengaruhi dalam proses penyusunan strategi dakwah. Hal ini penting diketahui dan dipahami oleh suatu organisasi, dikarenakan dinamika perkembangan zaman yang terus berubah pada setiap lini kehidupan telah mendorong perubahan pula dalam penetapan strategi.

Bila dicermati terdapat beberapa faktor yang turut berpengaruh dalam penyusunan strategi dakwah. Diantara faktor-faktor yang turut andil dalam mempengaruhi penentuan strategi adalah faktor lingkungan, baik itu yang berasal dari dalam organisasi itu sendiri (internal factor) ataupun faktor lain yang berasal dari lingkungan luar organisasi (eksternal factor).

Dalam bukunya Sondang, P Siagian mensinyalir setidaknya terdapat empat faktor dalam menentukan strategi yaitu: ${ }^{18}$

1 Faktor ekonomi.

Tidak hanya dalam organisasi profit, organisasi non-profit pun termasuk organisasi dakwah, dalam menentukan dan menerapkan strateginya bergantung pada SDM (sumber daya manusia) dan SDA (sumber daya alam) yang ia miliki. Hal tersebut dikarenakan program-program yang telah tersusun dalam

\footnotetext{
18 Sondang P. Siagian, Analisis serta Perumusan Kebijaksanaan, 107-108.
} 
suatu organisasi pastilah tidak akan bisa berjalan tanpa adanya SDM dan SDA yang mendukungnya.

Dalam hal ini ekonomi menjadi faktor utama yang berpengaruh dalam penerapan strategi suatu organisasi. Hal tersebut dikarenakan suatu organisasi dalam menentukan langkahnya pastilah akan berorientasi pada sumberdaya yang ada baik itu sumberdaya yang bersifat material atau immaterial. Meskipun target yang akan dicapai tinggi akan tetapi tanpa ada dukungan dari sisi materi maka dapat dipastikan target tersebut akan sulit terealisasi.

2 Faktor politik

Politik yang sedang hangat terjadi baik dalam lingkungan internal organisasi ataupun di luar organisasi turut pula berpengaruh pada strategi yang diterapkan dalam suatu organisasi. Politik yang mempengaruhi penetapan strategi dalam suatu organisasi ketika tidak disikapi dengan kemaslahatan bersama dalam pencapaian tujuan organisasi dapat membawa dampak buruk terhadap organisasi yang bersangkutan.

Organisasi bisa jadi hanya dimanfaatkan oleh segelintir orang yang tidak bertanggung jawab demi mencapai tujuan pribadinya. Sebagai suatu contoh "gap" yang terjadi antara personal anggota dalam suatu organisasi dikarenakan perbedaan politik, maka sudah pasti strategi yang telah dicanangkan kurang bisa terlaksana seperti apa yang menjadi tujuan organisasi tersebut.

3 Faktor dari implikasi kebijakan pemerintah

Kebijakan-kebijakan pemerintah yang berlaku dalam suatu negara tentunya berimbas pula pada semua lini kehidupan tak terkecuali dalam organisasi dakwah. Hal demikian dikarenakan peraturan yang ditetapkan oleh suatu pemerintah wajib dilaksanakan oleh semua lapisan masyarakat, dan hal inilah yang turut pula mewarnai dalam strategi dakwah yang diterapkan dalam suatu organisasi.

4 Faktor teknologi

Teknologi sebagai suatu sarana yang dimiliki oleh sebuah organisasi, tentunya akan mendukung penetapan strategi yang 
lebih baik dibandingkan dengan organisasi yang masih menggunakan data manual. Begitupula berlaku dalam suatu organisasi yang masih menggunakan peralatan yang seadanya, tentunya target dari strategi yang dihasilkan akan bergantung dari sarana dan prasarana yang mendukungnya. Organisasi dakwah yang telah memiliki seperangkat teknologi yang telah maju, memungkinkan menerapkan strategi dakwah dengan teknologi yang telah ada. Dari faktor-faktor yang tersebut di atas, dapat diketahui bahwa strategi dakwah yang diterapkan dalam suatu organisasi dakwah adalah sangat dipengaruhi dari faktor lingkungannya, baik itu lingkungan dalam ataupun lingkungan luar organisasi.

\section{Tekhnik dan Proses dalam Dakwah}

Dalam praktiknya agar strategi yang diterapkan oleh sebuah organisasi dapat berhasil maksimal dan tidak terjadi ketimpangan kebijakan, maka antara rencana strategis (renstra) dan rencana operasional (renop) haruslah berjalan sejajar guna mewujudkan visi dan misi dari strategi yang ditargetkan tersebut. Untuk mewujudkan hal tersebut, tentunya dibutuhkan tehnik-tehnik dalam penetapan strategi yang dimaksud. Dalam bukunya, Hadari Nawawi menyebutkan tehnik-tehnik yang bias digunakan antara lain: ${ }^{19}$

1 Teknik Matrik Faktor Internal dan Eksternal (The Internal and Eksternal Factor Matrix), yaitu penyusunan strategi dengan cara menganalisa dan mengevaluasi untuk mengetahui kelemahan dan kekuatan serta mengkaji peluang dan hambatan yang dihadapi dalam melaksanakan suatu misi, baik yang bersumber dari dalam atau luar organisasi.

2 Teknik Matrik Memperkuat dan Mengevaluasi Posisi (The Strengh Position and Evaluation Matrix), yaitu penyusunan strategi dengan cara mencocokkan sumber daya internal yang

\footnotetext{
${ }^{19}$ Hadari Nawawi, Manajemen Strategik, 174-177.
} 
dimiliki (kinerja organisasi) untuk memperkuat posisi dengan peluang yang ada, dan mengatasi atau menghindari resiko eksternal.

3 Teknik Matrik dari Kelompok Konsultas Boston (The Boston Consulting Group matrik), yaitu penyusunan strategi dengan cara menetapkan strategi yang berbeda-beda untuk setiap biro atau departemen sebagai satu unit kesatuan.

Dalam penyusunan suatu strategi dakwah, selain memerlukan suatu tekhnik penyusunan strategi seperti yang tersebut diatas, disisi lain juga harus mempertimbangkan tahapan-tahapan penyusunannya. Tahapan-tahapan dalam penyusunan strategi dakwah dimaksudkan agar lebih mudah dalam melakukan manajemen atas strategi dakwah yang akan diterapkan.

Adapun tahapan-tahapan dalam penyusunan strategi seperti yang dikemukakan oleh Triton PB dapat dikelompokkan kedalam enam tahapan penyusunan strategi. Adapun tahapan-tahapan tersebut adalah sebagai berikut:
a. Seleksi yang mendasar dan kritis terhadap permasalahan
b. Menetapkan tujuan dasar dan sasaran strategi
c. Menyusun perencanaan tindakan (action plan)
d. Menyusun rencana penyumberdayaan
e. Mempertimbangkan keunggulan
f. Mempertimbangkan keberlanjutan. ${ }^{20}$

Selanjutnya keenam langkah tersebut dapat dijabarkan sebagai berikut: Pertama, seleksi mendasar dan kritis terhadap permasalahan. Seleksi tersebut biasanya dilakukan berdasarkan faktor internal ataupun eksternal yang menjadi penyebab permasalahan dalam suatu organisasi dakwah. Adapun seleksi tersebut dapat dilakukan dengan langkah-langkah sebagai berikut:

1) Mengidentifikasi dan menginventarisasi seluruh permasalahan

2) Mengidentifikasi dan mengelompokkan masing-masing permasalahan berdasarkan faktor internal dan eksternalnya

${ }^{20}$ Triton PB, Marketing Strategic; Meningkatkan Pangsa Pasar dan Daya Saing, (Yogyakarta: Tugu Publiser, 208), 17. 
3) Mengurutkan permasalahan berdasarkan tingkat kepentinganya

4) Menentukan skala prioritas penyelesaian masalah

Kedua, menetapkan tujuan dasar dan sasaran strategi. Tujuan dasar dan sasaran yang hendak dicapai oleh suatu organisasi hendaknya tidak bertentangan dengan arah, cakupan, dan perspektif jangka panjang suatu organisasi, dikarenakan tujuan dan sasaran merupakan acuan yang menjadi dasar pengukiran berhasilnya strategi yang diterapkan. Ketiga, yaitu action plan. Dalam penyusunan strategi, biasanya terdapat dua tipe yang harus diperhatikan yaitu: rencana konsepsional (teoritis) dan rencana tindakan. Suatu rencana mungkin baik secara koseptual akan tetapi belum tentu sesuai atau baik dilapangan. Hal inilah yang kemudian sebuah strategi akan ditentukan oleh penyusunan rencana tindakan.

Oleh karena itu dalam penyusunan suatu strategi setidaknya harus memperhatikan langkah-langkah sebagai berikut: a. Meninjau kembali langkah-langkah dalam strategi yang akan mungkin diterapkan. b. Mengidentfikasi dan menginventarisasi faktor-faktor operasional, baik yang bersumber dari lingkungan internal ataupun eksternal.

Selain itu John M. Bryson mengemukakan bahwa untuk mencapai strategi yang tepat, maka suatu organisasi dituntut untuk memperhatikan langkah-langkah yang tepat pula di dalam menyusunanya. Adapun langkah-langkah tersebut seperti yang diungkapnanya adalah sebagai berikut: ${ }^{21}$

Pertama, yaitu memprakarsai dan menyepakati suatu proses perencanaan strategis. Hal ini dilakukan sebagai upaya untuk menegosiasikan suatu kesepakatan dengan orang-orang penting pembuat keputusan (decision maker), atau pembentuk opini (opini leaders) internal dan tidak mungkin menutup kemungkinan dari kalangan eksternal tentang seluruh upaya perencanaan strategi dan langkah perencanaan yang penting yang akan diterapkan. Dengan

${ }^{21}$ M. Mftahuddin. Perencanaan Strategis Sebagai Organisasi Sosial. Terjemah Jhon M Bryson, Strategik. Planning For Public And Nonprofit Organizations; A Guide Strengthering An Sustaining Organizational Achievent. (Yogyakarta: Pustaka Pelajar, 2001), 55-57. 
kata lain, dalam suatu organisasi harus terdapat beberapa orang atau kelompok yang memulai suatu proses di dalam penetapan suatu strategi, yang mana dalam suatu organisasi harus terdapat salah satu pemrakarsa yang menetapkan secara tepat siapa saja yang tergolong orang-orang penting pembuat keputusan. Ketika hal ini sudah bisa dilakukan maka langkah selanjutnya adalah menetapkan orang, kelompok, atau suatu unit organisasi yang harus dilibatkan dalam upaya perencanaan suatu strategi. Kesepakatan awal yang dihasilkan kemudian akan dinegosiasikan dengan setidak-tidaknya beberapa dari pembuat keputusan dalam organisasi tersebut. Kedua, yaitu memperjelas mandat organisasi. Tidak dapat dipungkiri, bahwa mandat yang terdapat dalam suatu organisasi memiliki kedudukan yang sangat krusial didalam dinamika roda suatu organisasi. Mandat yang bersifat formal ataupun informal yang ditempatkan pada suatu organisasi adalah merupakan suatu "keharusan" yang dihadapi oleh suatu organisasi yang bersangkutan. Dengan memperjelas mandate suatu organisasi, maka suatu organisasi dalam oprasionalnya dapat megetahui fungsi dan tugas, serta tujuan organisasi tersebut.

Ketiga, yaitu mempertegas dan memperjelas misi dan nilai-nilai yang diusung oleh suatu organisasi. Misi suatu organisasi yang dimaksud disini adalah misi yang berkaitan erat dengan mandatnya. Melihat sudut pandang tersebut, maka kehadiran suatu organisasi dapat dipahami sebagai suatu alat menuju akhir pencapaian tujuan, akan tetapi bukan akhir dari tujuan itu sendiri. Me mperjelas misi haruslah disusun lebih dari sekedar memperjelas keberadaan organisasi. Keempat, yaitu menilai lingkungan eksternal. Disini tim perencanaan harus mengeksplorasi lingkungan di luar organisasi untuk mengidentifikasi peluang dan ancaman yang akan dihadapi oleh suatu organisasi.

Kelima, yaitu menilai lingkungan internal. Untuk mengenali kekuasaan dan kelemahan internal, organisasi dapat memantau sumber daya (input), strategi sekarang (proses) dan kinerja (output). Karena sebagian besar organisasi biasanya mempunyai banyak informasi tentang input organisasi, seperti gaji, pasokan, bangunan fisik dan personalia yang sama dengan personalia purna waktu (full- 
time equivalent). Keenam, yaitu mengidentifikasi isu strategis yang dihadapi organisasi. Identifikasi terhadap isu-isu strategis akan dapat berjalan maksimal apabila kelima langkah sebelumnya sudah bisa dilakukan dengan baik. Perencanaan strategis memfokuskan kepada tercapainya sasaran yang terbaik antara organisasi dan lingkungannya. Oleh karena itu, perhatian kepada mandat dan lingkungan eksternalnya dapat dipikirkan sebagai perencanaan dari luar ke dalam (the outside in). Perhatian kepada misi dan nilai-nilai maupun lingkungan internal dapat dianggap sebagai perencanaan dari dalam ke luar (the inside out).

Ketujuh, yaitu merumuskan strategi untuk mengolah informasi dari isu-isu yang telah didapat. Strategi diidentifikasikan sebagai pola tujuan, kebijakan, program, tindakan, keputusan atau alokasi sumber daya yang menegaskan bagaimana organisasi harus mengerjakan hal itu. Strategi yang diterapkan organisasi satu dengan lainya dapat berbeda-beda dikarenakan tingkat, fungsi dan kerangka waktu yang diterapkan. Kedelapan, yaitu merumuskan suatu visi organisasi yang efektif untuk waktu yang aka datang. Langkah terakhir dalam proses perencanaan, organisasi mengembangkan deskripsi mengenai bagaimana seharusnya organisasi itu bertindak. Sehingga berhasil mengimplementasikan strateginya dan mencapai seluruh potensinya.

Dari praktiknya kedelapan langkah perencanaan strategis tersebut di atas juga harus memperhatikan hal-hal sebagai berikut:

- Strength (kekuatan). Yaitu strategi ini dibuat berdasarkan jalan pikiran organisasi dengan memanfaatkan keseluruhan kekuatan untuk memaksimalkan dan memanfaatkan kekuatan yang dimiliki organisasi.

- Weakness (kelemahan). Yakni strategi yang diterapakn dalam suatu organisasi haruslah berdasar pada kegiatan yang bersifat defensif dan berusaha meminimalisir kelemahan yang ada serta menghindari ancaman yang diprediksikan bisa timbul.

- Opportunity (peluang). Yakni strategi yang diterapkan haruslah berdasarkan pada pemanfaatan peluang yang ada dengan cara 
maminimalisir kelemahan yang ada serta menghindari ancaman.

- Threats (ancaman). Yakni strategi dalam menggunakan kekuatan yang dimiliki oleh organisasi untuk mengatasi ancaman. Dengan melihat keempat hal di atas, maka dapat diambil kesimpulan, dengan memperhatikan SWOT tersebut, maka sebuah organisasi akan dapat menjalankan programprogram yang telah disusun dan memperoleh hasil yang dikehendaki oleh organisasi.

\section{Tantangan Dakwah di Zaman Kontemporer}

Tantangan terberat dalam berdakwah adalah radikalisme. Radikalisasi agama menurut teori Martin E. Marty didapatkan ciriciri sebagai berikut:

1. Fundamentalisme. Sebagaimana diketahui, bahwa faham fundamentalisme sejatinya merupakan faham pemikiran yang mempunyai side-effect (dampak negatif) yang dapat membawa pelakunya menjadi militan terhadap ajaran yang dianutnya. Dalam hal ini faham-faham yang ada dalam masyarakat yang sering menganggap kafir orang yang tidak seidiologi, sering merasa golonganya yang paling benar, dan dalam menghukumi segala sesuatu harus dikembalikan pada ajaran agama yang murni.

2. Penolakan terhadap hermeneutika. Hal tersebut dapat dimaknai bahwa kaum radikal cenderung menolak terhadap suatu tafsir ayat. Mereka hanya mengkaji dan memaknai ayat apa adanya (tekstualis), kitab suci hanya dimaknai benar adanya tanpa mempertimbangkan rasionalitas (nalar) dan sabab nuzul ayat. Fenomena demikianlah yang nampaknya sering terjadi dalam masyarakat dan rentan menimbulkan adanya pertikaian dalam sutu masyarakat.

3. Penolakan terhadap pluralisme dan relativisme. Hal ini juga yang dikatakan bahwa kaum radikal pada prinsipnya hanya memandang ajaranya saja yang benar. Dalam pemutusan suatu hukum, mereka kurang mengabaikan kemajemukan masyarakat 
yang ada, mereka enggan menilai faham kelompok lain, melainkan hanya ajaran yang sesuai dengan apa yang mereka yakini saja yang dianggap benar.

4. Penolakan terhadap perkembangan historis dan sosiolgis.

Perkembangan ini dinilai oleh kaum radikalis sebagai muara ketidak sesuaian dalam keberagamaan, mereka menilai bukan AlQur'an yang harus mengikuti nalar, akan tetapi akal-lah yang seharusnya tunduk dan patuh terhadap semua nilai-nilai Al-Qur'an. Pada tahap tertentu, ketika nilai-nilai agama sudah tidak lagi diterapkan sesuai dengan apa yang menjadi pemikiran mereka, masyarakat sudah semakin tidak karuan, maka muncullah penolakan-penolakan terhadap sejarah yang ada, berbarengan dengan itu mereka tidak mau menerima Pancasila sebagai dasar negara dengan segala sejarah dan perjuanganya, akan tetapi konsep khilafah yang menjadi pikirnya.

Berdasarkan analisa dari teori sebagaimana disebutkan di atas, penulis mensinyalir bahwasanya radikalisme agama yang ada merupakan suatu bentuk upaya dari sekelompok masyarakat yang ingin menjadikan Al-Qur'an dan Hadits sebagai basic values (nilai dasar) dari segala aspek kehidupan. Prinsipnya radikalisme dipahami sebagai berikut:

a. Radikalisme agama difahami sebagai suatu ajaran dari suatu kelompok yang selalu membenarkan dirinya sendiri, dan tidak segan-segan menuduh kafir (takfir) terhadap golongan yang ia tidak sependapat denganya.

b. Kaum radikalis cenderung merasa sebagai kelompok yang paling memahami terhadap ajaran agama.

c. Kaum radikalis merupakan golongan yang kurang mengedepankan nilai- nilai toleransi dan tidak mau menghargai tradisi, pendapat dan keyakinan kelompok lain.

d. Pada umumnya kaum radkalis muncul dari cara memahami agama yang tertutup dan tekstual.

e. Kaum radikalis cenderung bersifat revolusioner dan menginginkan penerapan ajaran Islam secara total (kaffah) 
dan murni (puritan) dalam setiap lini kehidupan.

f. Dalam tata Negara, konsep yang mereka usung adalah konsep Khilafah (kepemimpinan menurut Islam) dan mereka kurang setuju tentang konsep demokrasi.

Dalam mewujudkan ideologinya, mereka berkedok jihad sebagai pembenaranya dan tidak segan-segan menggunakan cara kekerasan. Radikaisasi agama muncul disebabkan oleh kuatnya ideologi yang mereka anut. Stimulus yang mereka terima dari doktriner-doktriner pemimpinya mereka jadikan pedoman yang paling utama. Hal inilah yang nampaknya menjadikan mereka bersikap ekstream, tertutup, tidak mau menerima argumen orang lain bahkan disisi lain cenderung menganggap kafir orang yang berbeda ideologi dengan mereka. Orang-orang yang beroreintasi pada ajaran agama secara radikal pada hakikatnya mereka adalah orang-orang yang kurang bisa menghargai terhadap nilai-nilai perjuangan para leluhur yang telah rela berkorban dan memperjuangkan kemerdekaan. Konsep Kilafah yang mereka kedepankan, sejatinya juga merupakan konsep yang kontra-nasionalisme.

\section{Penutup}

Islam sejatinya merupakan agama yang "Rohmatan Lil Alamin". Ia senantiasa menjadi pembawa damai bagi manusia dan alam semesta yang ada di muka bumi ini. Akan tetapi apa jadinya apabila kehadiran Islam malah menjadikan momok yang menakutkan. Hal tersebut dikarenakan ada oknum yang berdalih memperjuangkan Islam, akan tetapi hanya dengan cara yang mereka benarkan tanpa memperdulikan aspek kemanusiaan dan lainya.

Seperti yang telah kita ma'lumi bersama, pada prinsipnya strategi dakwah merupakan suatu istilah yang tersusun dari dua suku kata yaitu strategi dan dakwah. Term pertama yaitu berasal dari bahasa Yunani yaitu "strategos" yang artinya tentara, dan term penyusun kalimat seajutnya yaitu "dakwah" berasal dari bahasa Arab yang artinya mengajak, menyeru dan memanggil. Istilah strategi oleh Awaludin Pimay, lebih diidentikkan dengan istilah 
“taktik" yang dapat berarti suatu jenis rencana yang digunakan untuk menentukan tindakan-tindakan dimasa yang akan datang dengan mempertimbangkan factor- faktor kekurangan dan kelemahan yang ada dari kondisi internal mataupun eksternal suatu organisasi. Secara umum strategi mempunyai pengertian suatu garis-garis besar haluan untuk bertindak dalam usaha mencapai sasaran yang telah ditentukan. Strategi adalah cara yang dipakai guna memecahkan dan menghadapi masalah tertentu yang sedang bergejolak sehingga ditemukan jalan keluar. Tantangan terbesar yang dihadapai dalam menerapkan dakwah adalah radikalisme. Radikalisasi agama saat ini menjadi isu yang aktual untuk dibicarakan. Negara Indonesia dengan kompleksitas etnis, suku dan agama tentunya mengundang berbagai problem di berbagai lini kehidupan masyarakat. 


\section{DAFTAR PISTAKA}

Abdurrahman, Pribadi Abu, Rayyan Membongkar Jaringan Terorisme, Jakarta: Abdika Press, 2009.

Ahmad, Baso. NU Studies; Pergolakan Pemikiran Antara Fundamentalisme Islam dan Fundamentalisme Neo-Liberal, Jakarta: Penerbit Erlangga, 2006.

Amirsyah. Meluruskan Salah Faham Terhadap Deradikalisasi; Pemikiran, Konsep, dan Strategi Pelaksanaan, Jakarta: Grafindo Hazanah Ilmu, 2012.

Hidayatulah, Syarif. Islam Isme-isme; Aliran dan Paham Islam di Indonesia, Yogyakarta: Pustaka Pelajar, 2010.

http://wartapedia.com/nasional/hukum-dan-kriminal/4334radikalisme-10-jaksa-siapkan-susunan-dakwaan-tersangkanii.html

http://www.eramuslim.com/berita/analisa/latar-belakang-munculnyastrategi deradikalisasi.htm

Ida, Waode. Kaum Progresif dan Sekularis Baru, Jakarta: Penerbit Erlangga, 2004.

Khamami, Zada. Islam Radikal; Pergulatan Ormas-Ormas Islam Garis Keras di Indonesia, Jakarta: Teraju, 2002.

Prasetyo, Eko. Dkk. Memahami Wajah Para Pembela Tuhan, Yogyakarta: Interfidie, 2004.

Rizky, Ahmad. dalam: Jurnal Ilmu Sosial dan Ilmu Politik Volume 14, Yogyakarta: FISIP UGM, 2010.

Rubaidi, A. Radikalisme Islam, Nahdlatul Ulama; Masa Depan Moderatisme Islam di Indonesia, Jatim: PWNU Jawa Timur, 2010.

Sabirin, Rahimi. Islam dan Radikalisme, Jakarta: Athoyiba, 2004. 
Sanwar, Aminuddin. Pengantar Ilmu Dakwah, Semarang: Fakultas Dakwah, 1986.

Shihab, Alwi. Membedah Islam di Barat; Menepis Tudingan Meluruskan Kesalahpahaman, Yogyakarta: Andi Offset, 2004.

Sidqi, Ahmad. dalam "Deradikalisasi Melalui Pesantren" diakses dari http://budisansblog.blogspot.com/2011/11/deradikalisasiberbasis-pesantren.html

Sulthon, Muhammad. Desain Ilmu Dakwah, Yogyakarta: Pustaka Pelajar, 2003.

Sumbulah, Umi. Islam Radikal dan PlularismeAgama: Studi Kontruksi Sosial Aktivis Hizb al-Tahrir dan Majelis Mujahidin di Malang tentang Agama Kristen dan Yahudi, Jakarta: BALITBANG RI, 2010.

. Konfigurasi Fundamentalisme Islam, Malang: UIN Malang Press, 2009.

Syu'aibi, Ali. Meluruskan Radikalisme Islam, Ciputat: Pustaka Azhary, 2004.

Turmudzi, Endang., Riza Sihbudi (ed). Islam dan Radikalisme di Indonesia, Jakarta: Lipi press, 2005. 